\title{
Study of porcine and human isophane (NPH) insulins in normal subjects
}

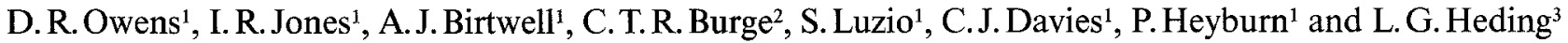 \\ ${ }^{1}$ Welsh National School of Medicine, Cardiff, ${ }^{2}$ Clinical Research Unit, Novo Research Institute, Cardiff, UK and \\ ${ }^{3}$ Novo Research Institute, Bagsvaerd, Denmark
}

\begin{abstract}
Summary. The plasma glucose, C-peptide and insulin responses to subcutaneously administered highly purified porcine, 'semi-synthetic' and 'biosynthetic' human isophane (NPH) insulin and diluting medium as control in normal male subjects were evaluated. Porcine and semi-synthetic human NPH insulins were administered at two dose levels of 0.15 and $0.30 \mathrm{U} / \mathrm{kg}$ body weight and biosynthetic human NPH at $0.15 \mathrm{U} / \mathrm{kg}$ body weight only. At the low dose level the three insulin preparations resulted in a similar maximal hypoglycaemic effect within 3-5 h after administration. However, over the remainder of the $11 \mathrm{~h}$ post-injection period, the plasma glucose level was lower after semi-synthetic human insulin. In contrast, at the $0.30 \mathrm{U} / \mathrm{kg}$ dose level, there was no difference
\end{abstract}

in the early or late hypoglycaemic response between porcine and semi-synthetic human NPH insulins of equivalent pharmaceutical formulation. The clinical relevance of these findings needs further evaluation. The data suggest that for the intermediate-acting' NPH insulin preparations, both the species of insulin, nature and quantity of the retarding protein and their subsequent interaction may determine their time-action characteristics.

Key words: Porcine NPH insulin, semi-synthetic and biosynthetic human NPH insulin, pharmacokinetics, pharmacodynamics, normal subjects.
In 1946 a neutral crystalline suspension of protamine insulin (NPH - Neutral Protamine Hagedorn), otherwise known as 'isophane insulin', was introduced [1]. This insulin preparation became popular as a once or twice daily insulin used alone or admixed with soluble insulin as required $[2,3]$. The advent of human insulin prepared either from porcine insulin by enzymatic conversion [4] or by employing recombinant DNA technology [5] has resulted in human NPH insulin becoming available for clinical use.

The purpose of this study was to compare the pharmacokinetics and pharmacodynamics of three NPH insulin preparations - porcine NPH insulin and both semi-synthetic and biosynthetic human NPH insulin following subcutaneous administration.

\section{Subjects, materials and methods}

\section{Subjects}

Six healthy normal male subjects, aged $24-38$ years, within $10 \%$ of their ideal body weight [6] and with no family history of diabetes mellitus were studied. The study was approved by the local Ethical Committee and informed consent was obtained from each of the volunteers.

\section{Materials}

Three different neutral NPH insulin preparations (U-40) were studied: (1) porcine NPH insulin (Protaphane MC, Novo Industri, Copenhagen, Batch No.501*2, expiry date: 01.02.83); (2) 'semi-synthetic' human NPH insulin produced by transpeptidation of porcine insulin (Protaphane HM, Novo, Batch No.103*2, expiry date: 01.09.83) and (3) 'biosynthetic' human NPH insulin produced by recombinant DNA technology (Humulin I, Eli Lilly, Indianapolis, USA, Batch No. X290A20A, expiry date: 01.09.84). Diluting medium (Novo, Batch No.7881, expiry date: 01.09.83) was used in the control studies. Determinations of insulin content of the three insulin preparations were carried out using a quantitative high pressure liquid chromatographic method: gel permeation chromatography method with porcine $\mathrm{MC}$ insulin as a standard. The calculated potency for porcine, semi-synthetic and biosynthetic human NPH insulins used in the study was $39.6,40.9$ and $40.5 \mathrm{IU} / \mathrm{ml}$ respectively. Other details relating to the protamine sulphate content and quantities of excipients in the three preparations and diluting medium studied are included in Table $1 \mathrm{~A}$ and $\mathrm{B}$.

\section{Methods}

All the subjects recruited were involved on six separate study days 1-2 weeks apart. Each study period commenced at $08: 00 \mathrm{~h}$ after a $10 \mathrm{~h}$ fast (time $-60 \mathrm{~min}$ ) with the siting of an IV cannula into an antecubital fossa vein connected to a slow running saline $(0.154 \mathrm{mmol} / \mathrm{l})$ infusion (approximately 1 litre $/ 8 \mathrm{~h}$ ). Frequent blood samples were obtained via a three-way tap. Following a basal period of $1 \mathrm{~h}$, the 
Table 1A. Contents of insulin preparations ( $1 \mathrm{ml} \mathrm{U} 40)$

\begin{tabular}{|c|c|c|c|}
\hline & \multicolumn{2}{|c|}{ Human NPH insulins } & \multirow{2}{*}{$\begin{array}{l}\text { Porcine NPH } \\
\text { insulin }\end{array}$} \\
\hline & Semi-synthetic & Biosynthetic & \\
\hline Insulin ${ }^{\mathrm{a}}(\mathrm{IU} / \mathrm{ml})$ & 40.9 & 40.5 & 39.6 \\
\hline $\begin{array}{l}\text { Protamine sulphate } \\
(\mathrm{mg})\end{array}$ & 0.142 & 0.144 & 0.145 \\
\hline Glycerol (mg) & 16 & 16 & 16 \\
\hline Metacresol (mg) & 1.5 & 1.6 & 1.5 \\
\hline Phenol (mg) & 0.65 & 0.72 & 0.65 \\
\hline
\end{tabular}

${ }^{a}$ Determined by quantitative high pressure liquid chromatography gel permeation chromatography method with monocomponent porcine insulin as standard

Table 1 B. Contents of diluting medium

\begin{tabular}{ll}
\hline & Diluting medium \\
\hline Sodium acetate $(\mathrm{mg})$ & 1.4 \\
Sodium chloride $(\mathrm{mg})$ & 7.0 \\
Methyl parahydroxybenzoate $(\mathrm{mg})$ & 1.0 \\
\hline
\end{tabular}

comparative insulins or diluting medium (control) were administered in a randomized fashion by SC injection into the anterior abdominal wall mid-way between the umbilicus and anterior superior iliac spine. A Plastipak SFP $1 \mathrm{ml}$ syringe (Becton-Dickinson, Brooklyn, New York, USA) was employed. The insulin preparations (1) and (2) were administered at 0.15 and $0.30 \mathrm{U} / \mathrm{kg}$ and (3) at $0.15 \mathrm{U} / \mathrm{kg}$ body weight.

During the basal (pre-injection) period, three venous blood samples were taken. Following SC injection, blood samples were taken every $30 \mathrm{~min}$ for $180 \mathrm{~min}$ and hourly thereafter up to $660 \mathrm{~min}$. The blood was aliquoted into fluoride for plasma glucose determination (hexokinase), heparin for immunoreactive insulin [7] and C-peptide measurements [8]. The blood was centrifuged within $5 \mathrm{~min}$ of sampling and the supernatants stored at $-20^{\circ} \mathrm{C}$ until assay. The detection limit of immunoreactive insulin was $0.022 \mathrm{pmol} / \mathrm{ml}$ and the sensitivity (SD within assay) was $0.009 \mathrm{pmol} / \mathrm{ml}$. The detection limit for C-peptide was $0.035 \mathrm{pmol} / \mathrm{ml}$ and the sensitivity $0.015 \mathrm{pmol} / \mathrm{ml}$. (Conversion: SI to traditional units: glucose: $1 \mathrm{mmol} / 1 \simeq 18 \mathrm{mg} / \mathrm{dl}$; IRI: $1 \mathrm{nmol} / 1 \simeq 5.8 \mathrm{ng} / \mathrm{ml}$ : C-peptide: $1 \mathrm{nmol} / 1 \simeq 3.02 \mathrm{ng} / \mathrm{ml}$ ). For each individual subject all samples were measured in one assay. Human and porcine insulins reacted identically in the insulin radioimmunoassay.

During each $12 \mathrm{~h}$ study period, the subjects remained supine and rested in a metabolic unit; they were monitored clinically and the site of injection inspected. No smoking was allowed during the study period, exercise was limited and standardised as far as possible and the room temperature was constant at $22^{\circ} \mathrm{C}$.

\section{Statistical analysis}

The results are expressed as mean $\pm \mathrm{SEM}$, and the comparisons were carried out using the paired Student's t-test. This method was preferred to analysis of variance as it does not require assumptions about variance homogenicity. The analyses were conducted on the absolute values and on the data after adjusting for the corresponding control values and pre-injection (basal) concentrations. In order to take into account the changes observed during the control day, the control day values for each subject have been subtracted from those obtained during the insulin test days. Also, to correct for the within and between subject variations during the $1 \mathrm{~h}$ pre-injection basal period, the resulting values were then adjusted for these differences using the mean of the three pre-injection levels for each study period.

\section{Results}

During the control day the plasma glucose concentration fell from $5.3 \pm 0.12 \mathrm{mmol} / 1$ at $-1 \mathrm{~h}$ to $4.6 \pm$ $0.13 \mathrm{mmol} / 1$ at $11 \mathrm{~h}$. Similarly, endogenous $\beta$-cell secretion was reduced over the $12 \mathrm{~h}$ study period as depicted by a lowering in plasma C-peptide from $0.42 \pm 0.05$ to $0.21 \pm 0.05 \mathrm{pmol} / \mathrm{ml}$ and insulin level from $0.055 \pm$ 0.007 to $0.028 \pm 0.003 \mathrm{pmol} / \mathrm{ml}$.

After the injection of porcine and semi-synthetic human $\mathrm{NPH}$ insulin at $0.15 \mathrm{U} / \mathrm{kg}$ body weight, the plasma glucose was lowered from a pre-injection level of $5.4 \pm$ $0.1 \mathrm{mmol} / 1$ to a nadir of $4.3 \pm 0.1 \mathrm{mmol} / 1$ at $4 \mathrm{~h}$ and $4.1 \pm 0.2 \mathrm{mmol} / 1$ at $3 \mathrm{~h}$ respectively (Fig. $1 \mathrm{~A}$ ). Subsequently a short-lived recovery in plasma glucose was observed $(+0.2-0.3 \mathrm{mmol} / \mathrm{l})$ over the ensuing $2 \mathrm{~h}$ period, although by $11 \mathrm{~h}$ the plasma glucose values had reverted to $4.4 \pm 0.2$ and $4.1 \pm 0.2 \mathrm{mmol} / \mathrm{l}$ for porcine and human insulin, respectively. There was no significant difference in the observed hypoglycaemic response to the two species of monocomponent NPH insulins (Fig. 1A). Comparison of the adjusted values, however, demonstrated a significantly greater hypoglycaemic response with semi-synthetic human NPH insulin at $6 \mathrm{~h}$ $(p<0.05)$ and $8 \mathrm{~h}(p<0.01$; Fig. 2A). Both insulins resulted in a similar reduction in the mean plasma C-peptide concentration to approximately $20 \%$ of the basal level by $5-8 \mathrm{~h}$ and which remained essentially unchanged up to the end of the study period (Fig.1A). With porcine NPH insulin the plasma insulin levels increased from $0.057 \pm 0.006 \mathrm{pmol} / \mathrm{ml}$ to a peak of $0.091 \pm 0.011 \mathrm{pmol} / \mathrm{ml}$ at $4 \mathrm{~h}$. Following semi-synthetic human NPH insulin with a similar pre-injection plasma insulin level of $0.055 \pm 0.007 \mathrm{pmol} / \mathrm{ml}$, a slightly earlier and higher mean peak level was observed at $3 \mathrm{~h}$ of $0.099 \pm 0.010 \mathrm{pmol} / \mathrm{ml}$ (Fig. 1 A). Comparison of the absolute values did not reveal any difference between porcine and human insulin, whereas the incremental insulin values were significantly higher with human insulin at $8 \mathrm{~h}(p<0.05$; Fig. $2 \mathrm{~A})$. By $6-8 \mathrm{~h}$ for both insulins, the mean plasma insulin concentrations had returned to basal levels.

In comparison with the low dose level the administration of both porcine and semi-synthetic human NPH insulins at the higher dose of $0.30 \mathrm{U} / \mathrm{kg}$ body weight resulted in a more rapid and greater fall in plasma glucose concentration (Fig. 1A and B). Starting from a similar pre-injection level of $5.2 \pm 0.1 \mathrm{mmol} / \mathrm{l}$, porcine and human insulin promptly lowered the plasma glucose reaching a nadir of approximately $3.5 \mathrm{mmol} / \mathrm{l}$ at 3 and $4 \mathrm{~h}$, respectively (Fig. 1 B). Subsequently, with both insulins, there was a small short-lived recovery in plasma glucose. There was no significant difference between the two insulins in their hypoglycaemic effect at $0.30 \mathrm{U} /$ $\mathrm{kg}$ (Figs. 1 B and 2B). A similar reduction in plasma C-peptide levels was observed with porcine and semisynthetic human NPH insulin, with values reaching $0.05 \mathrm{pmol} / \mathrm{ml}$ by $4 \mathrm{~h}$ post-injection, i.e. $10 \%$ of basal 
A

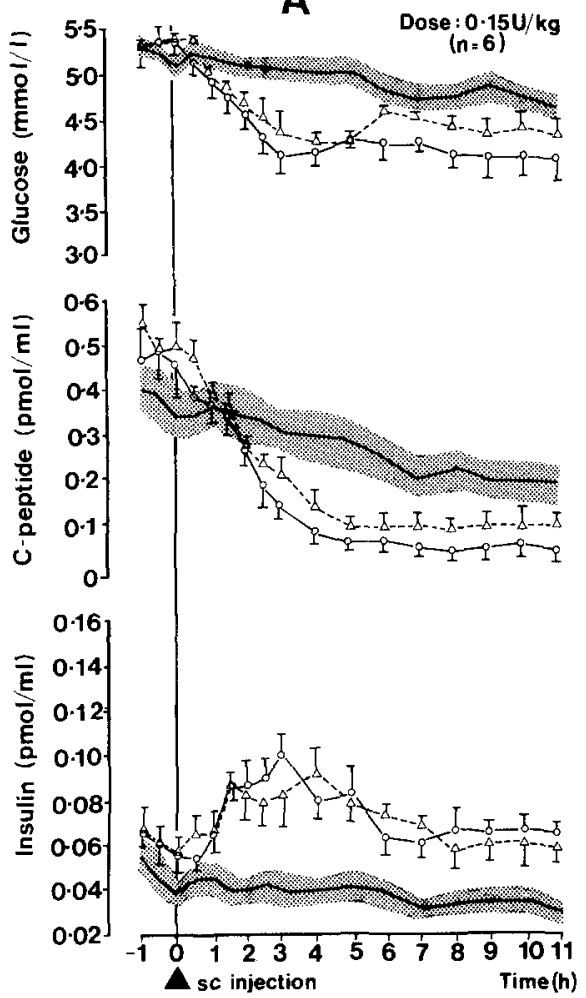

B

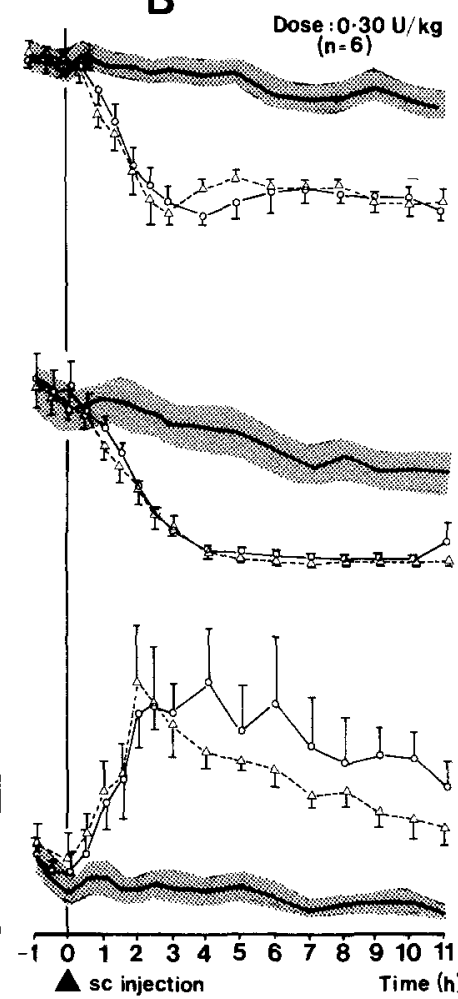

C

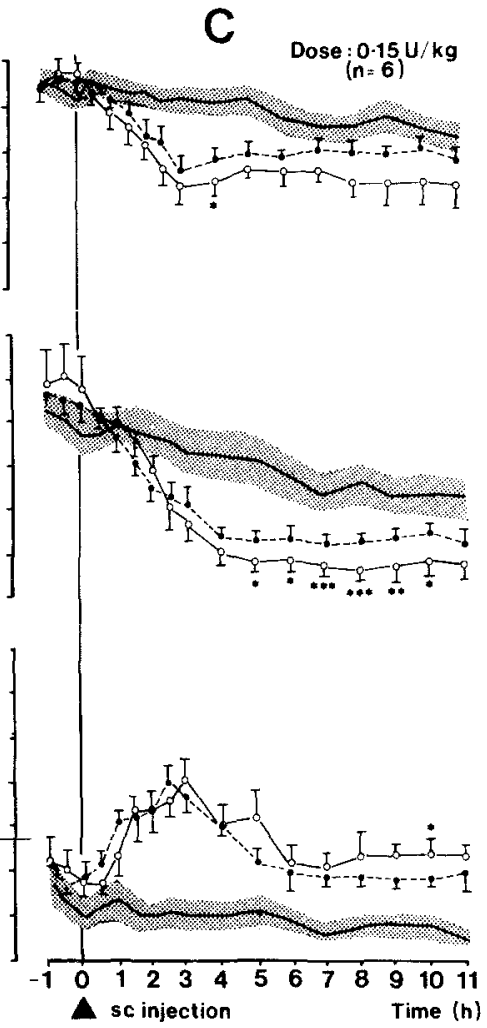

Fig. 1A-C. The mean \pm SEM plasma glucose, C-peptide and insulin levels in six normal male subjects following $\mathrm{SC}$ porcine $(\triangle----\triangle)$ and semi-synthetic human $(\mathrm{O}-\mathrm{O}) \mathrm{NPH}$ insulin at $\mathbf{A} 0.15$ and $\mathbf{B} 0.30 \mathrm{U} / \mathrm{kg}$ body weight; $\mathbf{C}$ semi-synthetic $(\mathrm{O}-\mathrm{O})$ and biosynthetic (- ) human NPH insulin at $0.15 \mathrm{U} / \mathrm{kg}$ body weight. Diluting medium was used for control studies. ${ }^{*} p<0.05 ; * * p<0.01 ; * * * p<0.001$
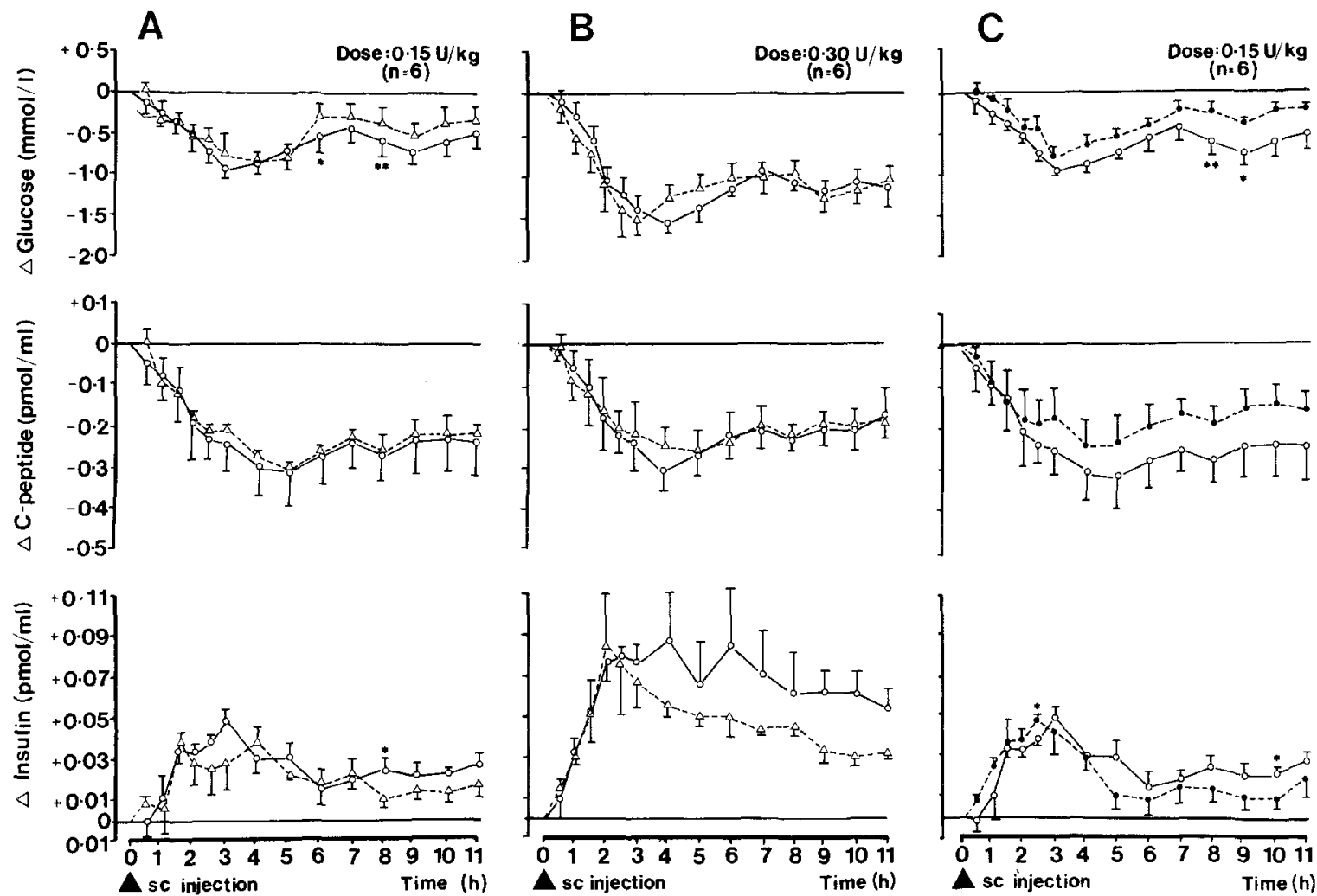

Fig. 2. The mean \pm SEM plasma glucose, C-peptide and insulin concentrations in six normal male subjects. Values adjusted for corresponding control day and basal (pre-injection) values $(\triangle)$ following SC porcine $(\triangle-\cdots \Delta)$ and semi-synthetic human $(O-O)$ NPH insulin at $\mathbf{A} 0.15$ and $\mathbf{B} 0.30 \mathrm{U} / \mathrm{kg}$ body weight; $\mathbf{C}$ semi-synthetic (O_- $)$ ) and biosynthetic ( ${ }^{*} p<0.05 ;{ }^{* *} p<0.01$ 
levels (Figs. 1 B and 2 B). Similar mean peak insulin levels were achieved following SC porcine and human insulin of $0.132 \pm 0.026$ and $0.133 \pm 0.023 \mathrm{pmol} / \mathrm{ml}$ at 2 and $4 \mathrm{~h}$, respectively. Thereafter the insulin levels fell more rapidly with porcine insulin reaching a value of $0.067 \pm 0.006 \mathrm{pmol} / \mathrm{ml}$ by the end of the study. The mean plasma insulin concentration with human insulin at $11 \mathrm{~h}$ post-administration was higher at $0.085 \pm 0.012$ $\mathrm{pmol} / \mathrm{ml}$.

Although there was a trend towards higher plasma insulin levels following human insulin from $4 \mathrm{~h}$ onwards there was no significant difference in the absolute or adjusted values (Figs. 1 B and 2B).

There was a significant dose-related effect on plasma glucose, C-peptide and insulin levels with both porcine and semi-synthetic human NPH insulin.

Biosynthetic human NPH insulin at the $0.15 \mathrm{U} / \mathrm{kg}$ dose level lowered the plasma glucose from a pre-injection level of $5.3 \pm 0.1$ to $4.3 \pm 0.2 \mathrm{mmol} / 1$ by $4 \mathrm{~h}$, with the values remaining between $4.4 \pm 0.1$ and $4.5 \pm 0.1$ $\mathrm{mmol} / 1$ until the end of the study (Fig. 1C). The plasma glucose lowering effect of biosynthetic human NPH insulin was significantly less than for semi-synthetic human insulin at 4 and $8 \mathrm{~h}(p<0.05$; Fig. 1C). This tendency was confirmed in the comparison of the adjusted data, demonstrating a significantly greater hypoglycaemic response with the semi-synthetic human NPH insulin at $8 \mathrm{~h}(p<0.01)$ and $9 \mathrm{~h}(p<0.05$; Fig. $2 \mathrm{C})$.

The plasma C-peptide level was reduced from $0.43 \pm 0.005 \mathrm{pmol} / 1$ to a nadir of $0.12 \pm 0.02 \mathrm{pmol} / \mathrm{ml}$ at $7 \mathrm{~h}$ after injection of biosynthetic human NPH insulin. The levels observed were significantly higher than after semi-synthetic human insulin from 5-10h $(p<$ 0.05-0.001; Fig. 1C), although the comparison of the adjusted data did not confirm this difference (Fig. 2C). Following the administration of biosynthetic human $\mathrm{NPH}$ insulin at $0.15 \mathrm{U} / \mathrm{kg}$, the plasma insulin levels increased from $0.057 \pm 0.006 \mathrm{pmol} / \mathrm{ml}$ at time $0 \mathrm{~h}$ to a peak mean level of $0.099 \pm 0.055 \mathrm{pmol} / \mathrm{ml}$ at $2.5 \mathrm{~h}$ (Fig. 1C). By $9 \mathrm{~h}$ after injection, the mean insulin concentration had reached pre-injection levels. The plasma insulin profile was similar for both human insulin preparations although the level was significantly higher $(p<0.05)$ with semi-synthetic human NPH insulin at the $10 \mathrm{~h}$ timepoint only (Fig. 1C). Comparison of the adjusted data revealed that a significantly higher insulin level was achieved with biosynthetic human NPH insulin at $2.5 \mathrm{~h}(p<0.05$; Fig. $2 \mathrm{C})$. Thereafter from $4 \mathrm{~h}$ onwards the mean incremental values were higher with semi-synthetic human NPH insulin, the difference reaching significance at $10 \mathrm{~h}(p<0.05 ;$ Fig. $2 \mathrm{C})$.

\section{Discussion}

It is only in the last decade that limited data on plasma insulin levels following the subcutaneous administration of NPH (isophane) insulin preparations have be- come available [9-14]. The use of plasma insulin measurements to characterize the pharmacokinetics of NPH insulins assumes that no protamine-zinc-insulin complexes are absorbed into the circulation. Bauman and Yalow have however demonstrated, using gel filtration, that some complexed insulin is in fact absorbed into the circulation [15].

Galloway et al. [14] did not demonstrate a difference in the hypoglycaemic response to purified porcine NPH and biosynthetic human NPH insulin in normal subjects at $0.15 \mathrm{U} / \mathrm{kg}$ body weight when administered subcutaneously in the deltoid area. The only difference observed was a higher serum insulin concentration following human insulin at $4 \mathrm{~h}$ after injection [16].

Analysis of the observed glucose response to porcine and semi-synthetic human NPH insulin in our study agrees with this impression. In contrast to previous investigation, our study design also allows the results to be corrected for the effect of prolonged fasting as seen during the control day. Using the corrected values and deriving the difference from the basal pre-injection concentrations demonstrates a significantly greater hypoglycaemic effect of human insulin between 6 and $8 \mathrm{~h}$ after administration at the $0.15 \mathrm{U} / \mathrm{kg}$ dose level. This was associated with a significantly higher plasma insulin level at $8 \mathrm{~h}$ with human insulin. There was however, no difference in the degree of $\mathrm{C}$-peptide suppression following the two insulins. Weinges et al. [17] using the Gerritzen test method in normal subjects observed a tendency towards a faster hypoglycaemic effect with biosynthetic human NPH insulin compared to purified porcine NPH insulin at a dose of $20 \mathrm{U}$ subcutaneously. In our study at a higher dose level of $0.30 \mathrm{U} / \mathrm{kg}$ (22-24 U), the hypoglycaemic response to porcine and semi-synthetic human insulin was identical. There was however a trend for higher insulin levels with human insulin from $3 \mathrm{~h}$ after administration to the end of the study period. Bottermann et al. [18] using the euglycaemic clamp technique also demonstrated a significantly higher plasma insulin level and dextrose infusion rate with human compared to porcine insulin. The evidence therefore suggests better bioavailability of human than porcine insulin from subcutaneous depot, possibly due to the greater hydrophilicity of human insulin $[4,5,19]$.

Interestingly, comparing semi-synthetic and biosynthetic human NPH insulins at $0.15 \mathrm{U} / \mathrm{kg}$, we observed a significantly greater hypoglycaemic effect with the former. Whilst a similar glucose nadir was achieved with both insulins at $3 \mathrm{~h}$ after administration, a quicker recovery towards normoglycaemia was seen with biosynthetic human NPH insulin. An extended observation period would be necessary to see if this trend persisted. The small differences in the protamine content is an unlikely explanation for the differences observed between the two human NPH insulins. The proportion of protamine insulin complexes absorbed may however have been different between the insulins, although this was not measured in this study. Recent clinical findings 
also suggest a trend towards a relatively shorter duration of blood glucose lowering effect with biosynthetic human NPH insulin in contrast to porcine or bovine $\mathrm{NPH}$ insulin preparations [20].

Our findings underline the importance of both insulin species and pharmaceutical formulation on the pharmacokinetic and pharmacodynamic profile of the NPH (isophane) insulin preparations examined.

According to the experimental procedure adopted involving normal fasting subjects the onset of hypoglycaemic action of the NPH insulins was evident within the first hour, the maximum effect observed between 3 and $4 \mathrm{~h}$ with a duration in excess of $11 \mathrm{~h}$. However, such idealized time-action characterization can only be of limited value in the clinical situation. Critical clinical evaluation is necessary to assess the relevance of the small differences observed between semi-synthetic and biosynthetic human NPH insulin.

Acknowledgements. This study was conducted with the technical help of Nursing Sisters M.Abouharb and R. Williams, Department of Medicine, Welsh National School of Medicine. We are grateful to Miss E. Andersen and Mr. A.C. Shaw for the illustrations and Mrs. J. Bracchi for typing the manuscript.

\section{References}

1. Krayenbühl C, Rosenburg T (1946) Crystalline protamine insulin. Rep Steno Hosp (Copenh) 1: 60-73

2. Hagedorn HC (1946) The absorption of protamine insulin. Rep Steno Hosp (Copenh) 1: 25-39

3. Oakley W, Hill D, Oakley N (1966) Combined use of regular and crystalline protamine (NPH) insulins in the treatment of severe diabetes. Diabetes 15:219-222

4. Markussen J, Damgaard U, Pingel M, Snel L, Sørensen AR, Sørensen E (1983) Human insulin (Novo): chemistry and characteristics. Diabetes Care 6 (Suppl 1): 4-8

5. Chance RE, Kroeff EP, Hoffman JA, Frank BH (1981) Chemical, physical and biological properties of biosynthetic human insulin. Diabetes Care 4: 147-154

6. Metropolitan Life Assurance Company (1960) Statistics bulletin. New York, No.41

7. Heding LG (1972) Determination of total serum insulin in insulin treated diabetic patients. Diabetologia 8: 260-266

8. Heding LG (1975) Radioimmunological determination of human C-peptide in serum. Diabetologia 11: 541-548

9. Ginsberg S, Block MB, Mako ME, Rubenstein AH (1973) Serum insulin levels following administration of exogenous insulin. $\mathbf{J}$ Clin Endocrinol Metab 6: 1175-1179

10. Malone JI, Root AW (1981) Plasma free insulin concentrations: keystone to effective management of diabetes mellitus in children. J Pediatr 6: 862-867

11. Lauritzen T, Pramming S, Gale EAM, Deckert T, Binder C (1982) Absorption of isophane (NPH) insulin and its clinical implications. Br Med J 285: 159-162

12. Galloway JA, Spradlin CT, Nelson RL, Wentworth Davidson JA, Swarner JL (1981) Factors influence the absorption, serum insulin concentration, and blood glucose responses after injections of regular insulin and various insulin mixtures. Diabetes Care 4: 366-376

13. Berger M, Cüppers HJ, Hegner H, Jörgens V, Berchtold P (1982) Absorption kinetics and biochemical effects of subcutaneously injected insulin preparations. Diabetes Care 5: 77-91

14. Galloway JA, Spradlin CT, Root MA, Fineberg SE (1981) The plasma glucose response of normal fasting subjects to neutral regular and NPH biosynthetic human and purified pork insulins. Diabetes Care 4: 183-188

15. Bauman WA, Yalow RS (1980) Differential diagnosis between endogenous and exogenous insulin-induced refractory hypoglycaemia in a non-diabetic patient. N Engl J Med 303: 198-199

16. Galloway JA, Root MA, Bergstrom R, Spradlin CT, Howly DC, Fineberg SE, Jackson RL (1982) Clinical pharmacological studies with human insulin (recombinant DNA). Diabetes Care 5 (Suppl 2): 13-22

17. Weinges K, Ehrhardt M, Nell G, Enzmann F (1982) Pharmacodynamics of human insulin (recombinant DNA) regular, NPH and mixtures - obtained by the Gerritzen method in healthy volunteers. Diabetes Care 5 (Suppl 2): 67-70

18. Bottermann P, Gyaram H, Wahi K, Ermler R, Lebender A (1982) Insulin concentrations and time-action profiles in three different intermediate-acting insulin preparations in non-diabetic volunteers under glucose-controlled glucose infusion technique. Diabetes Care 5 (Suppl 2): 43-52

19. Markussen $J$ (1982) The advent of human insulin in diabetic therapy. Medicographia 4 (No2): 39-44

20. Clark AJL, Adeniyi-Jones RO, Knight G, Leiper JM, Wiles PG, Jones RH, Keen H, MacCuish AC, Ward JD, Watkins PJ, Cauldwell JM, Glynne A, Scotton JB (1982) Biosynthetic human insulin in the treatment of diabetes. Lancet 2:352-357

Received: 10 June 1983

and in revised form: 9 February 1984

Dr. D. R. Owens

Department of Medicine

University Hospital of Wales

Heath Park

Cardiff CF4 4XW

UK 